\title{
Critical Thinking and Foreign Language Teaching
}

\section{Qingqing Liu}

School of Foreign Language, China West Normal University, Nanchong, Sichuan, China.

\begin{abstract}
The use of critical thinking in language teaching helps to cultivate the overall quality of talents. Therefore, critical thinking is of great significance to foreign language teaching. The paper starts with the concept and importance of critical thinking, briefly describes some of the difficult problems in foreign language teaching today, and finally puts forward the enlightenment of the cultivation of critical thinking on solving difficult problems in foreign language teaching.
\end{abstract}

Key Words: critical thinking; foreign language teaching; difficult problems; enlightenment

\section{Introduction}

After entering the 21 st century, quality education has increasingly become the main goal of education reform in all countries in the world. The focus of quality education is to cultivate students' creativity, and the key to creative cultivation is to cultivate students' critical thinking ability. Higher Education Law and 2010-2020 National Medium and Long-term Educational Reform and Development Plan Outline both clearly pointed out: the task of higher education is to cultivate high-quality professionals with innovative spirit and ability. In this process, especially in foreign language teaching, some difficult problems will inevitably be encountered, and the cultivation of critical thinking can help educators solve these problems to a certain extent.

\section{The Concept and Importance of Critical Thinking}

The cultivation of students' critical thinking ability is the key to quality education. Critical thinking can help people to take a critical view of social issues, and try to solve these problems instead of imitating others without dispute.

\subsection{The concept of critical thinking}

Critical thinking experts of the American Philosophy Association define critical thinking as judgments with purpose and reflection. On this basis, Peter A. Facione points out that critical thinking not only includes interpretation, analysis, reasoning, evaluation, interpretation, and self-adjustment, but also includes thinking habits such as curiosity, sharpness, persistence and truth-seeking. Dewey defines critical thinking as constantly reviewing thoughts and beliefs and inferring failures. Halperen defines it as the goal thinking to make decisions, explain or solve problems. Ennis defines critical thinking as the correct thought evaluation and reflection on our beliefs and what we have done.

In summary, critical thinking requires every individual to continuously think and reflect, to explain and evaluate their own thoughts or beliefs, to be willing to break decisions that have already been made, and to be good at accepting the different opinions of others.

\subsection{The importance of critical thinking}


Critical thinking is not only of great significance to our life, study and work, but also a tool for individual human beings to emancipate their minds and a way for human society to move towards democracy and civilization. Through continuous insight into new things and continuous reflection and thinking, it is conducive to the improvement of our academic performance and the enrichment of social experience.

From the perspective of emancipating the mind, critical thinking requires individuals to constantly reflect in order to seek a higher level of thinking. Neither blindly conservative nor blindly supporting new ideas, it guiding humans to explore more objective and fair ideas, and then respond to unreasonable ideas. The abandonment of the old things promotes the emancipation of human minds step by step.

From the perspective of human society moving towards democracy and civilization, if government agencies, administrators, and community leaders do not promote critical thinking, and are satisfied with those who are obviously irrational, illogical, biased, short-sighted and unreasonable in the decision-making process, there will be a series of blasphemous behaviors and incidents such as persecuting intellectuals, suppressing scientific research. Therefore, society should attach great importance to critical thinking, and humans should also actively learn critical thinking.

\section{Difficult Problems in Foreign Language Teaching}

As one of the main basic courses, foreign language will inevitably encounter some difficult problems in the teaching process. For example, in classroom teaching, teachers are often the center, ignoring students' dominant status. The teaching method is single, with little interactive discussion and debate. And this teaching evaluation system is outdated and cannot provide effective feedback to the classroom.

3.1 Take the teacher as the center and ignore students' dominant position.

Foreign language classroom should be a place for students to gain language input, conduct language exercises, and display learning results. According to the different situations of students, teachers should have different teaching plans. In today's foreign language teaching, some teachers still stick to their own ideas and put the status of teaching materials and teachers at the center of the classroom, which makes students still in a passive position in the choice of learning content and methods. As a result, students are gradually used to be leaded by teachers, with little emphasis on their own ability of choice and learning.

3.2 The teaching method is single, with little interactive discussion and debate.

Teachers pay attention to the instillation of information and lack the training of students' thinking ability. As a result, students often lose their interest in exploring knowledge and cultivating their critical thinking ability.

According to a survey of 50 foreign language classrooms in 9 schools by Sun Baoheng (2018), the traditional teaching method of teacher lectures and students passively listening and taking notes accounted for $84 \%$ of classroom time, and student debates and discussions only accounted for $8.5 \%$ of classroom time. It can be seen that the traditional teaching methods in foreign language teaching still dominate today, which makes students weaken in expression and speculation. Put it in another way, if students are passively taking part in learning activities or tasks, they may be less willingly to interact with others inevitably, which leads to few opportunities for exchanging ideas and cultivating communicative competence.

3.3 The teaching evaluation system is outdated and cannot provide effective feedback to the classroom.

With the continuous development of education, families and society pay close attention to the performance of students in school, and students' performance is the most intuitive display. Due to various pressures, school teaching has paid too much attention to the "one-stop" evaluation method, that is, students' final grades are used as the only criterion to their learning effect. This goes against the original intention of education to a large extent, and also reduces children's 
enthusiasm for learning in foreign language classes to a large extent.

Nowadays, combination of formative and summarizing assessment has become increasingly important. The evaluation of the process should attach importance to students' development, concern the individual difference, and make up for the shortage of final education. And the effects of the combination of formative and summarizing assessment has been proved by many experts and experienced teachers during the practice of language teaching. Conversely, summarizing assessment only put emphasis on students' final education, which ignores students' performance during the leaning process and cannot provide effective feedback to teachers, students and parents.

\section{The Enlightenment of the Cultivation of Critical Thinking on Solving Difficult Problems in} Foreign Language Teaching

First of all, critical thinking requires individuals to continuously reflect and evaluate, emphasizing the value of the individual, that is, critical thinking inspires the transformation of a teaching model based on teacher input to a teaching model based on student output. Secondly, critical thinking requires individuals to constantly ask questions, constantly evaluate themselves, and then form their own new views. Therefore, effective questioning and debate should be emphasized in the teaching process. Finally, Peter A. Facione proposed that critical thinking should consider the credibility and logic of judgments when evaluating students, in other words, when evaluating students' performance, they should consider their logic and consider whether the evaluation truly reflects the level of the students, which requires effective evaluation methods in foreign language teaching.

\subsection{Establish a student-oriented teaching model}

Foreign language teaching should fully embody the student as the main body and teachers should actively guide students, encourage them to discover, analyze, and solve problems, and cultivate students' self-learning consciousness, instead of echoing the views of others and self-denying. In addition, the role of the teacher is no longer a disseminator of knowledge in a narrow sense, but an intermediary. In the teaching process, the teacher also plays the role of guide, participant, promoter, evaluator, etc., The purpose of role transformation is to cultivate students' independent thinking ability and critical spirit. For example, teachers can create a democratic and harmonious atmosphere in the classroom to transform students' dull and passive learning state into an active learning state. As a result, teachers could lead students to think and reflect easily in an active learning atmosphere, and in return, to cultivate their critical thinking ability gradually.

In a word, in the classroom, teachers should scientifically and creatively design teaching activities and adopt flexible and diverse methods to make the classroom an important place for enlightening, guiding and cultivating students' active learning, autonomous learning, and practical application capabilities.

\subsection{Adopt diversified teaching methods}

To encourage students to think and reflect continuously, teachers should adopt diversified teaching methods, such as heuristic teaching, student mutual evaluation teaching, teamwork teaching and so on. In addition, teachers should also promote discussion-style or debate-style teaching to inspire students to explore problems in different ways. He Yunfeng (2000) believes that "questioning itself is a form of criticism". Critical thinking is essentially a questioning process, which gradually generates new views of the subject's own by asking different questions. For example, can a university manage the school by installing a camera lens? Through these kinds of questions, students can be motivated to think, analyze and solve problems. Teachers should encourage students to participate in classroom discussions, debates, and interactive communication, and learn to appreciate students' different views.

By adopting diversified teaching methods, there will be more opportunities for students to take part in different leaning patterns, as a result, different potentials and motivation could be inspired and motivated. For instance, during the 
process of continuous questioning, learners are able to think problems critically.

4.3 Use a process-based evaluation method

Critical thinking emphasizes the credibility and logic of the assessment, which inspires the foreign language classroom to abandon the traditional "one-stop" assessment method at the end of the term and conduct a comprehensive assessment of all aspects of student performance. Compared to summarizing assessment, formative assessment gives more emphasis to learners' performance during the learning process, and it adopts varieties of ways to record students' learning results, such as portfolio, diary and so on.

Teachers can comprehensively consider students' performance in classroom presentations, book reports, and unit tests. Therefore, in the ordinary teaching process, teachers should pay attention to observing and recording the performance of students in all aspects, and affirm the progress of students in a timely manner, and to help students' deficiencies rather than letting them go. For example, teachers can ask students to write reading notes. That is to say, when they read an article, they can write down questions and evaluations. As a result, when the teacher evaluates the performance of the students, they can take students' reading notes into the assessment scope.

In addition, In the actual teaching process, teachers should pay attention to the tests of students' logic, reasoning and language perception abilities in language learning. The assessment can be divided into multiple times, and the method of combining classroom assessment and after-school assessment, and combining stage assessment and final assessment is adopted. The content of the assessment should include the thinking methods involved in language learning and the key points of critical thinking, with the goal of improving students' thinking skills and cultivating students' critical thinking.

\section{Conclusions}

As the goal of quality education, critical thinking emphasizes the ability of independent thinking and judgment, which is a quality of thinking that every individual should possess. With the development of education, there are more and more difficult problems faced in foreign language classrooms, such as teacher-centered, single teaching method, outdated teaching evaluation system and so on. Integrating critical thinking into foreign language teaching can help the foreign language classroom to form a student-centered, diversified teaching method, and a process-oriented evaluation system. It also helps cultivate students' critical thinking ability.

\section{Conflicts of Interest}

The author declares no conflicts of interest regarding the publication of this paper.

\section{References}

[1] Ali Mohammad S., Narges K., Mohammad H. Y. (2015). Scrutiny of Critical Thinking Concept. International Education Studies. (3): 93-102.

[2] Chen Z.W. (2019). Foreign Language Teaching Design Integrating Critical Thinking Skills. Journal of Shandong Agricultural Engineering College. (5): 173-176.

[3] Facione P. A. (2015). Critical Thinking: What It Is and Why It Counts. Insight Assessment, 1-30.

[4] Gao Y.Q., Li J. (2019). Research on the Cultivation Path of Critical Thinking Ability in Foreign Language Teaching. Ability and Wisdom, 97-98.

[5] He X.Q., He S.R. (2010). On the Cultivation of Students' Critical Thinking in Foreign Language Teaching. Teaching \& Administration, 70-71.

[6] He Y.F. (2000). On Critical Thinking. Social Science Journal, (6): 15-18.

[7] Li R.F., (2002). Foreign Language Teaching and the Cultivation of Students' Creativity and Critical Thinking. Foreign Language Education, (23): 61-64. 
[8] Liu R.Q. (2015). Cultivation of Critical Thinking in Foreign Language Teaching. China Adult Education, 134-135.

[9] Shu D.F. (2014). Problems and Research Topics in Foreign Language Classroom Teaching. Foreign Language Teaching and Research, (46): 446-455.

[10] Sun B.H., Zhang X.Y. (2018). Critical Thinking Teaching Model and Its Reference and Enlightenment to Foreign Language Teaching Reform. Journal of Shanxi Youth Vocational College. (31): 110-112.

[11] Sun Y.Z. (2011). Emphasize the Cultivation of Thinking Ability, and Deepen the Teaching Reform of English Majors. Foreign Language in China, (3): 49-58.

[12] Zhang X.Q. (2009). On the Construction of Critical Thinking in Foreign Language Teaching. Education and Vocation, (32): 95-97. 